Original article

DOI: $10.2478 / 10004-1254-65-2014-2450$

\title{
Occurrence of black Aspergilli in indoor environments of six countries
}

\author{
János Varga ${ }^{1}$, Sándor Kocsubé ${ }^{1}$, Gyöngyi Szigeti ${ }^{1}$, Nikolett Baranyi ${ }^{1}$, Csaba Vágvölgyi ${ }^{1}$, Daniela \\ Jakšić Despot ${ }^{2}$, Donát Magyar ${ }^{3}$, Martin Meijer ${ }^{4}$, Robert A. Samson, and Maja Šegvić Klarić \\ Department of Microbiology, Faculty of Science and Informatics, University of Szeged, Szeged, Hungary ${ }^{1}$, Department \\ of Microbiology, Faculty of Pharmacy and Biochemistry, University of Zagreb, Zagreb, Croatia ${ }^{2}$, National Institute of \\ Environmental Health, Budapest, Hungary ${ }^{3}$, CBS Fungal Biodiversity Centre, Utrecht, The Netherlands ${ }^{4}$
}

\author{
Received in October 2013 \\ CrossChecked in October 2013 \\ Accepted in January 2014
}

\begin{abstract}
Black Aspergilli (Aspergillus section Nigri) are widely distributed in various habitats. They act as food spoilage organisms, human pathogens, and mycotoxin producers and are frequently encountered in indoor environments. Black Aspergilli, specifically A. niger, A. welwitschiae, and A. carbonarius, produce different ochratoxins and fumonisins. Ochratoxins are known to induce renal disorders following inhalation, which necessitates the determination of potential mycotoxin-producing species in our environment. This paper aimed to compare the diversity and species distribution of black Aspergilli in the indoor environments of six different countries using morphological and molecular methods. A total of 178 black Aspergillus isolates were identified from six countries. In contrast with results from previous studies, $A$. niger was not the only black Aspergillus detected in indoor air. Species distribution differed among countries, although the distribution in European countries (Croatia, Hungary, the Netherlands, and Turkey) with a temperate climate was considerably similar. The highest species diversity was observed in indoor samples from Thailand, while the lowest was found in Algeria. Potentially ochratoxin- and fumonisin-producing fungi were detected in the indoor air of all six countries. Further studies need to clarify the effect of these fungi and their mycotoxins on human and animal health.
\end{abstract}

KEY WORDS: Aspergillus section Nigri; indoor fungi; calmodulin gene; sequence-based identification; species distribution

Moulds are widely distributed in indoor and outdoor environments. They are essential components of our ecosystem providing decomposition of many organic substances necessary for plant, animal, and human life (1). However, excessive exposure to moulds has been a health issue for humans for many years, as they are frequently found in homes, office buildings, schools, vehicles, and other locations where organic matter and water are left unattended. They are common in household dust and can cause allergic symptoms or invasive infections in humans with weak immune systems. They can also be harmful considering their toxin-producing abilities (2).
Black Aspergilli (Aspergillus section Nigri) are important in food mycology, medical mycology, and biotechnology, frequently occurring in indoor environments $(1,3)$. Many species cause food spoilage, but are also used in the fermentation industry to produce various enzymes and organic acids (4). Some species also act as plant pathogens, including A. carbonarius and A. niger in grapes, and $A$. welwitschiae in onions and the plant Welwitschia mirabilis $(5,6)$. Moreover, several species can produce mycotoxins including ochratoxins and fumonisins that can be harmful for both humans and animals (4, 6-9). Although data regarding fumonisin absorption 
following inhalation and/or dermal exposure are not available (10), ochratoxin A exposure via inhalation has been described in the literature to cause kidney disease in animals and humans (11), which is why precise identification at the species level is of immense importance. Recent data indicate that Aspergillus section Nigri comprises 25 species (4, 12-14), which can be divided into five main clades. The $A$. niger clade includes 10 biseriate species and was divided into three subclades based on $\beta$-tubulin and calmodulin sequence data: the $A$. tubingensis, $A$. niger, and $A$. brasiliensis subclades (13). Recently A. awamori was described (15) and later renamed $A$. welwitschiae, while $A$. acidus was renamed $A$. luchuensis (16). Some of these species are able to produce carcinogenic mycotoxins including ochratoxins and fumonisins $(4$, 17). Black Aspergilli isolated from indoor air are usually referred to as A. niger (18). Black Aspergilli were found in indoor air in several countries including Great Britain, the Czech Republic, Egypt, Saudi Arabia, the US, Canada, and Slovakia (18). In general, they occur more frequently in tropical or subtropical areas $(18,19)$.

Although they are common in indoor environments, the species composition of black Aspergilli is unknown. That is why the aim of this work was to compare the diversity and species distribution of black Aspergilli in indoor environments of various countries using morphological and molecular methods.

\section{MATERIALS AND METHODS}

The samples used were obtained from six different countries as part of interlaboratory cooperation and comparison. Samples of airborne fungi were collected in Croatia, Hungary, the Netherlands, Turkey, Algeria, and Thailand between 2010 and 2013 using standard methods. The Petri plate sedimentation method or airsamplers using dichloran 18\% glycerol agar (DG18) plates were used for sampling airborne fungi (1, 20). The plates were incubated at $25 \pm 2{ }^{\circ} \mathrm{C}$ and the developed fungal colonies were counted 5 days later. Airborne fungi were identified on the basis of their macro- and microscopic characteristics after subculturing on Czapek Yeast Agar (CYA) and Malt Extract Agar (MEA) (1). Black Aspergillus isolates $(\mathrm{n}=178)$ were purified and cultivated on CYA and MEA plates at $25{ }^{\circ} \mathrm{C}$ in the dark for seven days. Morphological identifications were carried out according to literature $(1,4,21)$.
For sequence-based identification, the cultures used for the molecular studies were grown on malt peptone (MP) broth for 2 days, and DNA was extracted from the mycelia using the Masterpure ${ }^{\mathrm{TM}}$ yeast DNA purification kit (Epicentre Biotechnologies, Madison, WI, USA) according to the manufacturer's instructions. A part of the calmodulin gene was amplified and sequenced as described previously (4). The calmodulin sequences were compared using nucleotide-nucleotide BLAST (blastn) with default settings (22) with the Genbank database and our own sequence database. Species identification was determined from the lowest expected value of BLAST output.

\section{RESULTS AND DISCUSSION}

In this preliminary study, the species distribution of black Aspergilli was examined in various indoor environments of six countries using sequence-based methods. Since the sampling methods varied, a detailed analysis of the quantitative distribution of species was not possible. Consequently, we instead concentrated on the species distribution of the isolates. Altogether, 178 black Aspergillus isolates were obtained and examined using morphological methods. In accordance with the literature, these isolates could not be reliably assigned to species based on their macro- or micromorphological features, with the exception of $A$. carbonarius, which produces larger conidial heads and conidia than the other species (4). However, the isolates were successfully assigned to species using partial sequence data of the calmodulin gene, which is in agreement with previous studies (4, 13).

The observed species distributions were highly variable in the examined countries (Figure 1). The examined isolates from Thailand showed the greatest diversity; 22 isolates belonged to 7 different species among which 2 isolates represented a new species related to Aspergillus saccharolyticus (23) and will be characterized in future studies, especially regarding their genetic and chemical profiles. The smallest diversity was observed in the Algerian dataset, where only 2 species could be observed. Interestingly, $A$. carbonarius, commonly found in various types of environments and significant for its ability to produce high quantities of ochratoxin A $(4,24)$, was observed only in this country. The diversity of black Aspergilli was similar in European countries. Four species were identified in Hungary and the Netherlands while 5 


\section{Hungary $(n=73)$}

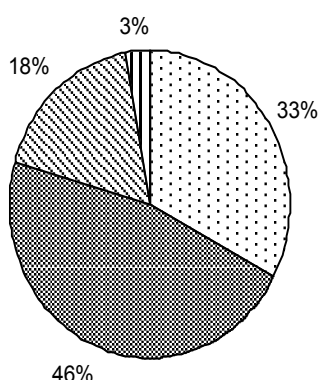

๑. niger

A. welwitschiae

A. tubingensis

口A. luchuensis
Netherlands $(n=14)$

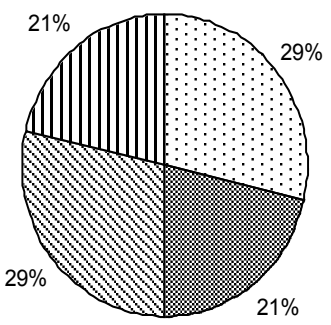

$\square$ A. niger

A. welwitschiae

A. tubingensis

$\square$ A. luchuensis

Thailand $(n=22)$

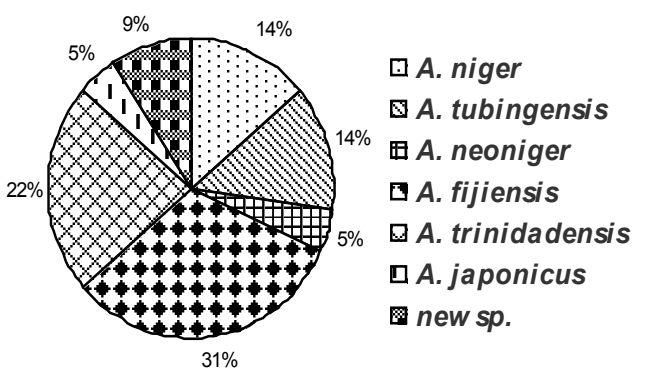

Turkey $(n=12)$



A. welwitschiae

A. tubingensis

๓ A. Iuchuensis

$\square$ A. uvarum

๑. aculeatinus
Algeria $(n=16)$

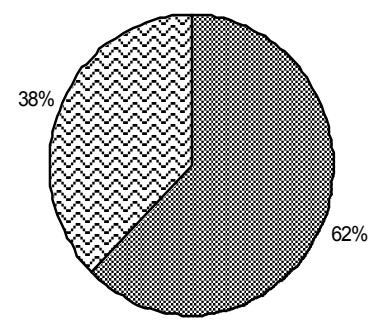

A. welwitschiae

$\checkmark$ A. carbonarius

Figure 1 Distribution of black Aspergillus species in indoor environments in different countries based on their calmodulin sequence data.

$n$-represents the number of strains in section Nigri

species were identified in Croatia. Interestingly, the species distributions were very similar: A. niger, $A$. tubingensis, A. luchuensis, and $A$. welwitschiae were identified in all three countries. In Turkey, $A$. tubingensis, A. luchuensis, and A. welwitschiae were also present, whereas $A$. niger was not detected. However, in this country the sample size was relatively small, since only 12 black Aspergilli could be isolated.

In summary, in contrast to previous studies, $A$. niger was not the only black Aspergillus present in indoor air. Species diversity was different in the countries examined, although the species distributions in European countries with temperate climate were highly similar. A. niger, A. tubingensis, A. luchuensis, and $A$. welwitschiae were identified in three of the
European countries, as well as in Turkey, with the exception of $A$. niger, indicating the significant role of climatic conditions on the distribution and occurrence of indoor fungi. At least one of the potentially ochratoxin- and fumonisin-producing fungi A. niger, A. welwitschiae, and A. carbonarius was detected in all six countries. Further studies are needed to clarify the real impact of these fungi and their mycotoxins on human and animal health.

\section{Acknowledgements}

The research of S.K., Sz.Gy., N.B. and Cs.V. was supported by the European Union and the State of Hungary, co-financed by the European Social Fund in the framework of TÁMOP 4.2.4.A/2-11-1-2012-0001 
"National Excellence Program". The relating research groups were also supported by the project TÁMOP 4.2.2.A-11/1/KONV-2012-0035 and by the Hungarian Scientific Research Fund (OTKA; grant reference number No. K84122 and K84077), providing infrastructure and research equipment.

\section{REFERENCES}

1. Samson RA, Houbraken J, Thrane U, Frisvad JC, Andersen B. Food and indoor fungi. Utrecht: CBS-KNAW Fungal Biodiversity Centre; 2010.

2. Jarvis BB, Miller JD. Mycotoxins as harmful indoor air contaminants. Appl Microbiol Biotechnol 2005; 66:367-72.

3. Schwab CJ, Straus DC. The roles of Penicillium and Aspergillus in sick building syndrome. Adv Appl Microbiol 2004; 55:215-38.

4. Samson RA, Noonim P, Meijer M, Houbraken J, Frisvad JC, Varga J. Diagnostic tools to identify black Aspergilli. Stud Mycol 2007; 59:129-45.

5. Varga J, Kocsubé S, Szigeti G, Man V, Tóth B, Vágvölgyi C, Bartók T. Black Aspergilli and fumonisin contamination of onions purchased in Hungary. Acta Aliment 2012; 41:41423.

6. Nielsen KF, Mogensen JM, Johansen M, Larsen TO, Frisvad JC. Review of secondary metabolites and mycotoxins from the Aspergillus niger group. Anal Bioanal Chem 2009; 395:1225-46.

7. Frisvad JC, Larsen TO, Thrane U, Meijer M, Varga J, Samson RA, Nielssen KF. Fumonisin and ochratoxin production in industrial Aspergillus niger strains. PLoS ONE 2011; 6:e23496.

8. Šegvić Klarić M. Adverse effects of combined mycotoxins. Arh Hig Rada Toksikol 2012; 63:519-30.

9. Piecková E. Adverse health effects of indoor moulds. Arh Hig Rada Toksikol 2012; 63:545-9.

10. European Commission. Opinion of the Scientific Committee on Food on fusarium toxins part 3: Fumonisin $\mathrm{B}_{1}$ (FB1). European Commission Health and Consumer Protection Directorate-General, Brussels, Belgium; 2000.
11. Di Paolo N, Guarnieri A, Garosi G, Sacchi G, Mangiarotti AM, Di Paolo M. Inhaled mycotoxins lead to acute renal failure. Nephrol Dial Transplant 1994; 9(Suppl 4):116-20.

12. Samson RA, Houbraken JAMP, Kuijpers AFA, Frank JM, Frisvad JC. New ochratoxin or sclerotium producing species in Aspergillus section Nigri. Stud Mycol 2004; 50:45-61.

13. Varga J, Frisvad JC, Kocsubé S, Brankovics B, Tóth B, Szigeti G, Samson RA. New and revisited species in Aspergillus section Nigri. Stud Mycol 2011; 69:1-17.

14. Jurjević Z, Peterson SW, Stea G, Solfrizzo M, Varga J, Hubka V, Perrone G. Two novel species of Aspergillus section Nigri from indoor air. IMA Fungus 2012; 3:159-73.

15. Perrone G, Stea G, Epifani F, Varga J, Frisvad JC, Samson RA. Aspergillus niger contains the cryptic phylogenetic species A. awamori. Fungal Biol 2001; 115:1138-50.

16. Hong SB, Lee M, Kim DH, Varga J, Frisvad JC, Perrone G, Gomi K, Yamada O, Machida M, Houbraken J, Samson RA. Aspergillus luchuensis, an industrially important black Aspergillus in East Asia. PLoS ONE 2013; 8:e63769.

17. Varga J, Kocsubé S, Suri K, Szigeti Gy, Szekeres A, Varga $\mathrm{M}$, Tóth B, Bartók T. Fumonisin contamination and fumonisin producing black Aspergilli in dried vine fruits of different origin. Int J Food Microbiol 2010; 143:143-9.

18. Piecková E. Aspergillus sp. in dwellings and health implications of indoor fungi. [Displayed 29 September 2013]. Available at http://www.aspergillus.org.uk/indexhome. htm? secure/articles/./pieckova.html main

19. Scott JA. Studies on indoor fungi. Ph D Thesis. Toronto: University of Toronto; 2001.

20. Amend SA, Seifert KA, Samson RA, Bruns TD. Indoor fungal composition is geographically patterned and more diverse in temperate zones than in the tropics. Proc Natl Acad Sci USA 2010; 107:13748-53.

21. Raper KB, Fennell DI. The genus Aspergillus. Baltimore: Williams and Wilkins; 1965.

22. Altschul SF, Gish W, Miller W, Myers EW, Lipman DJ. Basic local alignment search tool. J Mol Biol 1990; 215:403-10.

23. Sørensen A, Lübeck PS, Lübeck M, Nielsen KF, Ahring BK, Teller PJ, Frisvad JC. Aspergillus saccharolyticus sp. nov., a black Aspergillus species isolated in Denmark. Int J Syst Evol Microbiol 2011; 61:3077-83.

24. Varga J, Kozakiewicz Z. Ochratoxin A in grapes and grapederived products. Trends Food Sci Technol 2006; 17:72-81. 


\section{Sažetak}

\section{Rasprostranjenost crnih plijesni roda Aspergillus u unutarnjem prostoru u šest država}

Crne plijesni roda Aspergillus široko su rasprostranjene u različitim životnim prostorima. Razgrađivači su hrane, ljudski patogeni i proizvođači mikotoksina. Također ih se često može pronaći u unutarnjim prostorima, a pojedine vrste poput $A$. niger, $A$. welwitschiae i $A$. carbonarius proizvode ohratoksine i fumonizine. Udisanje ohratoksina uzrokuje poremećaje bubrežne funkcije, pa je iznimno važno odrediti plijesni u našem okolišu koje bi ih mogle proizvoditi. U ovom se radu uspoređuje raznolikost i rasprostranjenost vrsta crnih plijesni roda Aspergillus u unutarnjem prostoru šest različitih zemalja morfološkim i molekularnim metodama. Analizirano je ukupno 178 uzoraka. Za razliku od prethodnih studija, u zraku unutarnjih prostora nije pronađena samo A. niger. Rasprostranjenost vrsta u europskim zemljama (Hrvatska, Mađarska, Nizozemska i Turska), gdje je klima umjerena, bila je umnogome slična. Najveća raznolikost uočena je u uzorcima iz Tajlanda, a najmanja u Alžiru. Da bi se razjasnili štetni učinci navedenih plijesni i mikrotoksina na zdravlje ljudi i životinja, potrebna su daljnja istraživanja.

KLJUČNE RIJEČI: gen za kalmodulin; identifikacija zasnovana na slijedu baza; plijesni unutarnjih prostora; rasprostranjenost vrsta

\section{CORRESPONDING AUTHOR:}

\section{János Varga}

Department of Microbiology

Faculty of Science and Informatics, University of Szeged

Közép fasor 52, 6726 Szeged, Hungary

E-mail:jvarga@bio.u-szeged.hu 